\title{
Mesterséges INTELLIGeNCIA ÉS AZ E-LEARNING: AZ ONLINE OKTATÁS JÖVŐJE
}

\author{
ÁBRAHÁM ZSOLT ${ }^{\mathrm{a}, \mathrm{b}}$ \\ ${ }^{a}$ Budapesti Corvinus Egyetem Gazdálkodástudományi Doktori Iskola \\ ${ }^{\mathrm{b}}$ Case Solvers
}

Beérkezett: 2021. január 12., elfogadva: 2021. február 6.

Matthew Montebello: AI Injected E-learning: The Future of Online Education. (Studies in Computational Intelligence.) Cham, 2018. Springer, xix $+86 \mathrm{p}$. ISBN: 978-3-319-67928-0.

Talán még sosem volt annyira aktuális az e-learning rendszerek szerepéről beszélni, mint napjainkban, amikor a hétköznapok valóságát feje tetejére állította egy korábban ismeretlen vírus, a COVID-19. Munkavállalók, egyetemi hallgatók, tanulók millióinak kellett egyik napról a másikra áttérniük otthoni munkavégzésre, távolról történő oktatásra és tanulásra. A köz-és felsőoktatásnak a társadalmi távolságtartás és a vírus elleni védekezés jegyében néhány nap leforgása alatt kellett átállnia a digitális oktatásra.

$\mathrm{A} z$ alábbi recenzió tárgya Matthew Montebello AI Injected E-learning: The Future of Online Education című könyve, mely az e-learning fejlődését mutatja be, és egyúttal kísérletet tesz egy lehetséges jövőbeli, mesterséges intelligencia által vezérelt modell kialakítására.

$\mathrm{A} z$ e-learning rendszerek evolúciós áttekintése során a legtöbb szerző szerint a távoktatás jelenti a kiindulópontot. Habár a távoktatás igénye már a 18 . században megjelent, jelentős fejlődési ugrást a 20 . század informatikai és digitális fejlődése tett lehetővé. A távoktatás megjelenése arra a problémára reflektált, amikor a diák és/vagy oktató nem tudott ugyanabban a térben és/vagy időben együtt tartózkodni, így a személyes jelenlétet valamilyen közvetítő médiummal kellett pótolni. Kezdetben ez a médium a levél, a rádió, később a telefon volt.

$\mathrm{A} z$ e-learning fejlődése során Montebello három generációt különböztet meg: 1. elektronikus kor; 2. HTML-éra és 3. a szemantikus web korszaka. Az e-learning rendszerek megjelenése a '60-as évek végére tehető, ekkor jelentek meg az első, oktatáshoz kapcsolódó, információk megosztását lehetővé tevő hálózatok (pl. Arpanet). Ez az elektronikus hálózat a korábbiakhoz hasonlóan az elektronikus üzenetet használta médiumként, ám az IP (Internet Protocol) és az FTP (File Transfer Protocol) megjelenésével lehetővé vált a fájlok megosztása, elküldése, mely napjainkig az e-learning rendszerek alapját jelenti. Az internet és a világháló kialakulása és fejlődése jelentette az e-learning rendszerek második generációját. A weboldalak és a weboldalak létrehozása során használt HTML (Hyper-Text Markup Language) nyelv széles körü elterjedésével lehetővé vált az információk változatos 
formában és széles körben történő bemutatása. A webes alkalmazással lehetővé vált az információk böngészése, nem volt szükség az egyes programok folyamatos letöltésére és frissítésére. $\mathrm{A} z$ úgynevezett CGI (Common Gateway Interface) protokoll, valamint a sütik (cookies) megjelenésével lehetővé vált a tartalom differenciálása, személyre szabása. A szemantikus web és az XML (eXtensible Markup Language) jelenti az e-learning rendszerek harmadik generációját; itt már a tartalom szisztematikus differenciálása, címkékkel történő ellátása is megjelenik.

A bemutatott evolúción keresztül lehetővé vált a tartalom menedzsmentje, a vegyes tanulás (blended learning), valamint a kollaboratív eszközök alkalmazása a tanulás során. Az e-learning rendszerek hatékonyságának vizsgálata során Montebello a MOOC (Massive Open Online Courses), a Crowdsourcing, valamint a közösségi hálózatok (social networks) tanulást segítő funkcióit tekinti át.

$\mathrm{A} z$ elmúlt időszakban az oktatás jelentősen kinyílt, széles rétegek számára is elérhetővé vált. $\mathrm{A} z$ e-learning rendszerek által nyújtott lehetőségeken keresztül a korábban zárt, erősen elitista képzések (például az ismert amerikai üzleti iskolák képzései) alapvető áruvá (commodity) váltak. Az egyetemek monopóliuma jelentősen átalakult, új oktatási formák és modellek jelentek meg, és váltak ismertté. A MOOC is egy ilyen koncepció, amely célja az ismeretanyag széles körü online átadása kurzusokon keresztül. A MOOC platformok talán legismertebb példái a Coursera (www.coursera.org) és a Udacity (www.udacity.com), ahol a felhasználók több száz online kurzus közül választhatnak szabadon.

A crowdsourcing (közösségi ötletbörze) koncepciója 2005-ben született, amikor Jeff Howe és Mark Robinson azt vizsgálták, hogy vállalkozások hogyan tudnak bizonyos feladatokat kiszervezni internetes felhasználóknak. A crowdsourcing során a felhasználók egyénileg vagy csoportosan vesznek részt egy-egy nyilvánosan kiszervezett feladat vagy probléma megoldásában. Az egyik legismertebb példa a Wikipédia, ahol felhasználók ezrei végzik az emberiség által birtokolt tudás és ismeretek rögzítését és strukturálását. Egy másik példát jelentenek a saját szakmai érdeklődésem középpontjában álló esettanulmány-versenyek, amikor is esettanulmány formájában történik egy nyilvános problémafelvetés, majd a versenyre jelentkező csapatok külön-külön vagy együttmüködve oldják meg az adott esettanulmányban definiált problémát, és egy szakmai grémium előtt prezentálják az arra adott megoldási javaslatukat. A crowdsourcing tehát egy olyan eszköz, melynek segítségével közös erőforrásokat mozgósítva komplexebb feladatokat tudnak a felhasználók megoldani az online (és offline) térben.

A közösségi hálózatok megjelenésével és elterjedésével a tanulók számára lehetővé vált az egymás közötti, nyilvános és magánjellegü interakció, véleménycsere. Napjainkra a felhasználók több készüléken keresztül folyamatosan az internethez és a különböző közösségi oldalakhoz kapcsolva töltik idejüket, ami a kapcsolati tanulás elmélete (connectivity learning theory) szerint lehetőséget teremt a tanulók számára a világ különböző pontjairól és szakértőitől származó információ és tudás gyors összegyüjtésére és összevetésére. A közösségi hálózatok e-learning rendszerekbe történő integrálásával a tanulás is egyfajta közösségi élménnyé vált.

Jelenleg számos trend alakítja az e-learning rendszereket, és ezek különböző modelleket eredményeztek az elmúlt évtizedben. Az egyes modellek a tanulás egy-egy aspektusát ragadják meg, legyen 
szó személyre szabott, differenciált tartalomról, közösségi problémamegoldásról vagy online közösségi kapcsolatok kialakításáról, közösségi tanulásról.

Montebello könyvében egy, a mesterséges intelligencia (AI - Artificial Intelligence) lehetőségeivel kiegészített modellre tesz javaslatot. A modell mögötti infrastruktúra három pillérre épül és kínál megoldást a hatékonyság vizsgálata során azonosított három kulcsproblémára. $\mathrm{A}$ javasolt modell integráltan kezeli az olyan, a mesterséges intelligencia által mozgatott, úgynevezett intelligens elemeket, mint a crowdsourcing, a tanulók profilozása, valamint a személyre szabás.

A szerző szerint a jelenleg is használt e-learning rendszerek nem használják ki a bennük rejlő potenciált és nem müködnek hatékonyan. A szerző az e-learning hatékonyságának vizsgálata során három tényezőt azonosított, amelyek kihívás elé állítják ezen rendszerek tervezőit és üzemeltetőit: 1 . a motiváció hiánya; 2. elszigeteltség; valamint 3. személytelenség.

A kurzusokon részt vevő tanulók motivációja rendkívül sokszínü. Ráadásul mindig vannak, akik végig lelkesek maradnak, és befejezik a képzést, míg mások lemorzsolódnak. A motiváció fenntartása kulcsfontosságú egy hatékony e-learning rendszer kialakítása során. A tanulók motivációja sokféle lehet, de az egyik legalapvetőbb belső motivációs tényező a tananyag érdekességének függvénye. Tang és McCalla (2004) szerint folyamatos visszacsatolás kérésével lehet naprakészen testre szabott tananyaggal fenntartani a tanulók motivációját.

$\mathrm{A} z$ online interakciók ellenére sok tanulóban megvan az igény a személyes interakcióra. Bousaaid és mtsai (2015) kimutatták, hogy a tanulók ritkán szeretnek magányosan tanulni, és a közösségi hálózatokkal megtámogatott e-learning folya- mat sokkal hatékonyabb, mint az izolált tanulás.

A tananyag és a tanulási folyamat személytelensége ez esetben a személyre szabottság hiányát, a sablonokra épülő, túl általános tartalmat jelenti. A személyre szabott tapasztalat ugyanis az egyediség, a megkülönböztetettség és a különlegesség percepcióját erősíti a tanulóban. $\mathrm{Ez}$ az a tényező, amely megkülönbözteti a felhasználót a tömegtől.

A javasolt modell tehát az e-learning rendszerek kritikusai által megfogalmazott három legjelentősebb kihívást veszi górcső alá, integrált megoldást nyújtva a korábbiakban megfogalmazott kritikákra.

A mesterséges intelligencia által vezérelt e-learning rendszer infrastruktúrája három egységből áll: 1. személyes tanulási hálózat (PLN - Personal Learning Network); 2. személyes tanulási portfólió (PLP - Personal Learning Portfolio); valamint 3. az ezeket magában foglaló személyes tanulási környezet (PLE - Personal Learning Environment).

A személyes tanulási hálózat koncepciója nagymértékben épül a kapcsolati tanulás elméletére. A személyes tanulási hálózat az összekapcsolódó eszközökön és a széles körű közösségi kapcsolódásokon keresztül képes kezelni az elszigeteltség, izoláltság problémáját.

A tanulói profilok és tanulmányi portfólió a diákok formális és informális akadémiai tapasztalatát összegzik. Magukban foglalják az elvégzett kurzusokat, a kapcsolódó értékeléseket, visszajelzéseket, valamint a felmért készségeket és egyéb kvalifikációkat. A tanulási portfólió folyamatosan változik, fejlődik, így minden e-learning rendszer számára kritikus a frissítés, a folyamatos aktualizálás. A személyes tanulási portfólió szervesen illeszkedik az önrendelkezési tanuláselmélethez (self-determination learning theory), és egy olyan eszközt jelent, amely folyama- 
tosan képes fenntartani a tanulók motivációját.

A személyes tanulási hálózat és a személyes tanulási portfólió, valamint a személyre szabás elegyeként jön létre a személyes tanulási környezet. Ez olyan környezetet jelent, amely emberközeli, és személyes akadémiai atmoszférát teremt a felhasználó számára, biztosítja arról, hogy a tananyag kialakításakor személyes érdeklődését, szükségletét, oktatási előképzettségét is figyelembe vették. Egy ilyen környezetben a tanuló választhat az egyes feladatok, funkciók között, ezzel is személyesebbnek élheti meg a képzést. A személyes tanulási környezet kialakítása az adaptív tanuláselméletből (adaptive learning theory) indul ki, miszerint a hatékony tanulási folyamat megteremtése érdekében alkalmazkodni kell a tanuló igényeihez.

A Montebello által javasolt e-learning rendszert a mesterséges intelligencia által nyújtott eszközök és algoritmusok teszik egyedivé. A könyvben bemutatott modell három, a mesterséges intelligencia által algoritmizálható eszközt javasol az úgynevezett intelligens tanulási környezet megtervezésekor és kialakításakor: 1. közösségi ötletbörze; 2. tanulók profilozása (learner profiling); valamint 3. személyre szabás.

A modell a közösségi ötletbörzén keresztül biztosítja, hogy senki se érezze elszigetelten magát. Mivel mindenki egy személyes tanulási hálózat (PLN) tagja, ezért könnyen kapcsolódhat más, hasonló érdeklődésü tanulókhoz. Mindezt a digitális társadalom teszi lehetővé, miszerint napjainkra a tanulók többsége több közösségi hálózat tagjaként képes hozzáférni a legújabb akadémiai vívmányokhoz.

A tanulók motivációjának fenntartása érdekében fontos, hogy az e-learning rendszerek a tanulók szakmai igényeihez igazodjanak. A személyes tanulási portfólió (PLP) folyamatosan változik, a mes- terséges intelligencia a visszacsatolásokon keresztül rendszeresen kap információt a tanuló változó érdeklődési köréről, és szükség esetén magát az algoritmust igazítja a változó preferenciákhoz.

A tanulási folyamat és az egész e-learning tapasztalat mesterséges intelligencia segítségével történő személyre szabásának alapvető feltétele a szakmai tartalomnak, a tanulási folyamatnak, valamint a közvetítő médiumnak a tanuló igényeihez történő igazítása. Mindehhez személyre szabott, intelligens tanulási környezetre (PLE) van szükség, amely kezeli a személytelenség problémáját.

A javasolt modell lényege az érdeklődés felkeltése, a felhasználó folyamatos megismerése, profilozása, majd a kapott információk alapján a tartalom (pl. tananyag, prezentációk, számonkérés) és a tanulási élmény (pl. képernyők, gombok, ikonok) személyre szabása. Mindez úgy történik, hogy a mesterséges intelligencia a kapott információkat folyamatosan „tanulja”, majd miután a mögöttes algoritmusokon keresztül „megismerte” a felhasználót, magától tesz egyedi, személyre szabott javaslatokat a tanuló számára.

Montebello könyvében bemutatja, miként müködhet egy, a tanulók érdeklődési körére épülő, hatékony e-learning rendszer. A szerző modellje lehet, hogy elsőre utópisztikusnak tűnik, különösen a digitálisnak mondott oktatás kényszerü valósága után, de mindenképp egy fontos irányt jelöl ki vele a szerző. A könyv olvasásakor egyértelmüvé válik, hogy a hatékony e-learning rendszer nem azonos a közösségi média üzenetküldő alkalmazásain keresztül történő videós oktatással, és nem is azonos az otthonra emailben kiadott házifeladatokkal, hanem egy annál jóval komplexebb, az e-tanulásélmény hiányosságaira is reflektáló rendszer.

A Montebello-féle modell azonban számos etikai, valamint adatvédelmi kér- 
dést is felvet. A szerző által javasolt rendszer a tanulók megismerésén, úgynevezett tanulói profilok kialakításán alapul, melyekre a mesterséges intelligencia személyre szabott szakmai tartalmat javasol. Hol az oktató személyének a határa? Mi $a z$, amit gépekkel lehet és szabad helyettesíteni? Az iskola egy nagyon fontos szocializációs közeg. Vajon a mesterséges intelligencia képes-e az emberiség számára fontos értékek átadására? Ehhez hasonló etikai kérdések sorát veti fel a mesterséges intelligencia alkalmazása az oktatás terén. Ugyanez vonatkozik a javasolt modellre is, hiszen a tanulók profilozása, a teljesítmény ilyen jellegü mérése rendkívüli körültekintést igényel az adatkezelés terén. Ezeket a dilemmákat a szerző könyvében nem tárgyalja, noha kétségte- len, hogy a mesterséges intelligencia alkalmazásának egyik legfontosabb aspektusát jelentik.

Mindezek ellenére Montebello modellje fontos lépést jelenthet a minőségi oktatás és képzés felé. Egyetemi oktatóként, trénerként és kompetenciaméréssel foglalkozó szakemberként is úgy gondolom, hogy napjainkra az információ és a tárgyi ismeretekre épülő tudás széles körben vált elérhetővé. $\mathrm{A} z$ online töltött idő mellett folyamatosan növekszik az információkhoz köthető online zaj is, így megjelent az igény egyfajta validált teljesítménymérésre is. Az AI Injected E-learning: The Future of Online Education címü könyvben bemutatott, mesterséges intelligencián alapuló e-learning rendszer erre a növekvő igényre is egyfajta választ adhat.

\section{IRODALOM}

Bousaaid, M., Ayaou, T., Afdel, K. \& Estraillier, P. (2015) System Interactive Cyber Presence for E-learning to Break Down Learner Isolation. International Journal Computer Applications, Vol. 111. No. 16. pp. 975-8887. https://doi.org/10.5120/19626-1544

TAng, T. \& McCalla, G. (2004) Beyond Learners Interest: Personalized Paper Recommendation Based on Their Pedagogical Features for an E-learning System. Lecture Notes in Computer Science, 3157. pp. 301-310. https://doi.org/10.1007/978-3-540-28633-2_33

A cikk a Creative Commons Attribution 4.0 International License (https://creativecommons.org/licenses/ by-nc/4.0/) feltételei szerint publikált Open Access közlemény, melynek szellemében a cikk bármilyen médiumban szabadon felhasználható, megosztható és újraközölhető, feltéve, hogy az eredeti szerző és a közlés helye, illetve a CC License linkje és az esetlegesen végrehajtott módosítások feltüntetésre kerülnek. 